\title{
Heavy metals in two host-parasite systems: tapeworm vs. fish
}

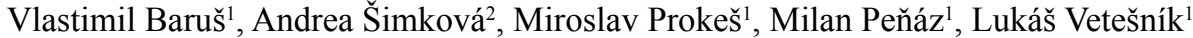 \\ ${ }^{1}$ Institute of Vertebrate Biology AS CR, v.v.i., Brno, Czech Republic \\ ${ }^{2}$ Masaryk University Brno, Faculty of Science, Department of Botany and Zoology, Brno, Czech Republic
}

Received January 16, 2012

Accepted May 16, 2012

\begin{abstract}
The tissue of two tapeworm species (Ligula intestinalis and Bathybothrium rectangulum) and body muscles of their fish host species were analyzed for heavy metal concentrations by standard methods using atomic absorption spectrometry. Regarding the values of accumulation ratio, the L. intestinalis accumulated 12.5-18.9 $\times$ more lead, 2.3-3 $\times$ more cadmium, and 4.4-14.1 $\times$ more chrome, compared to respective metal concentrations in muscles of cyprinid intermediate fish hosts. The gravid strobila biomass of the $B$. rectangulum accumulated $2.2 \times$ more lead, $1.2 \times$ more nickel, and $2.3 \times$ more chrome compared with the respective concentrations in the muscles of the barbel Barbus barbus. Metal concentrations in the muscles of uninfected fish and by tapeworm infected barbels showed that the uninfected individuals exhibited $1.4 \times$ more lead, $1.6 \times$ more nickel and $1.7 \times$ more chrome than the infected ones. Our study suggests that parasites are a useful bioindicator when evaluating environmental pollution of aquatic ecosystems by heavy metals.
\end{abstract}

Ligula, Bathybothrium, cyprinid fishes

The accumulation and concentration of heavy metals in aquatic organisms (especially in fish) has been investigated in the Czech Republic on a long-term basis (see review by Peňáz et al. 1980, 2002; Svobodová and Hejtmánek 1985; Svobodová et al. 1996, 1999; Spurný et al. 2009; Valová et al. 2010). Interest in the study of the heavy metal bioaccumulation potential in the strobila of adult tapeworms parasitizing in the intestines of both freshwater and marine fishes increased in the last decade of the past century (Riggs et al. 1987; Sures and Taraschewski 1995; Taraschewski and Sures 1996; Sures et al. 1997ab, 1999; Turčeková and Hanzelová 1996, 1999). Previous studies were focussed also on larval stages of parasites and heavy metal concentrations were analyzed in plerocercoids of the tapeworm Ligula intestinalis (L.) parasitizing in the body cavity of cyprinids (Gabrashanska and Nedeva 1996; Svobodová et al. 1996; Tenora et al. 1997, 2000; Baruš et al. 1999, 2001). Pascoe and Cram (1977) studied the accumulation of cadmium in plerocercoids of a related tapeworm species Schistocephalus solidus (Müller, 1776). Studies published until now have documented also the theoretical and practical problems of heavy metal concentrations in the strobila of tapeworms and in the tissues (mostly muscles and liver) of their intermediate and/or definite fish hosts. The aim of this study was to analyze heavy metal concentrations in two different parasite species and their host species from the natural aquatic environment of the Czech Republic.

\section{Materials and Methods}

Several host-parasite systems with the following sample size (n) were analyzed. First, three host species, i.e. common bream Abramis brama (L.) $(\mathrm{n}=10)$, white bream Blicca bjoerkna $(\mathrm{L}).(\mathrm{n}=15)$ and roach Rutilus rutilus (L.) $(\mathrm{n}=10)$ parasitized by Ligula intestinalis were studied. The plerocercoids of this tapeworm and samples of fish muscles (of age 3+ and older) from 3 localities (i.e. Mostiště, Dalešice and Nové Mlýny reservoirs) were sampled in 1992-1995 and studied. Next, barbel Barbus barbus (L.) $(\mathrm{n}=7)$ infected by Bathybothrium rectangulum (Bloch, 1782) was studied in the same season of 2004. The tapeworm strobila and muscles of parasitized fish (of age 4+ and 5+) from the barbel zone in the fishing region of Jihlava River were analyzed. 
In addition, fish species non-infected by this parasite, of the same age and from the same locality $(\mathrm{n}=5)$, and samples of macrophytes - water crowfoot (Batrachium fluitans Lam.) $(\mathrm{n}=3)$ were analyzed.

Heavy metal concentrations (lead - $\mathrm{Pb}$, cadmium - $\mathrm{Cd}$, chrome - $\mathrm{Cr}$ and nickel - Ni) were determined by means of atomic absorption spectrometry (AS) with the apparatus GBC - 932 A (USA) (for more details see Baruš et al. 1999, 2001). The contents of heavy metals were expressed in $\mathrm{mg} \cdot \mathrm{kg}^{-1}$ of $100 \%$ dry matter. The coefficient $\mathrm{R}$ (ratio) was also calculated to evaluate the efficiency and differences in heavy metals concentrations in the parasite biomass and muscles of hosts as the proportion of the parasite and host heavy metals concentrations (following Sures et al. 1999).

\section{Results}

Heavy metal concentrations in host-parasite systems including Ligula intestinalis and their cyprinid fish hosts are shown in Table 1. Concentrations of the detected heavy metals $(\mathrm{Pb}, \mathrm{Cd}, \mathrm{Cr})$ accumulated in the biomass of $L$. intestinalis plerocercoids were higher than those in the muscles of three intermediate host fish (A. brama, B. bjoerkna and R. rutilus). According to the R-values, $\mathrm{Pb}$ is the most efficiently accumulated element, followed by $\mathrm{Cr}$ and $\mathrm{Cd}$ (see Table 1). When comparing three species analyzed in this study, the lowest $\mathrm{R}$-values were found in roach and the highest ones in common bream. Similar R-values of Cd were found in three host species.

Table 1 . Heavy metal $(\mathrm{Pb}, \mathrm{Cd}$ and $\mathrm{Cr})$ concentrations $\left(\mathrm{mg} \cdot \mathrm{kg}^{-1}\right.$ in $100 \%$ dry matter $)$ in plerocercoids of tapeworm Ligula intestinalis and in muscles of parasitized fish (Abramis brama, Blicca bjoerkna and Rutilus rutilus; according to Tenora et al. 2000, supplemented)

\begin{tabular}{lccccccccc}
\hline \multicolumn{10}{c}{ Antermediate host } \\
\hline \multicolumn{9}{c}{ Abramis brama } & \multicolumn{3}{c}{ Blicca bjoerkna } & & \multicolumn{2}{c}{ Rutilus rutilus } \\
\hline Heavy metals & parasite & muscle & $\mathrm{R}$ & parasite & muscle & $\mathrm{R}$ & parasite & muscle & $\mathrm{R}$ \\
\hline $\mathrm{Pb}$ & $3.40 \pm 0.05$ & $0.18 \pm 0.05$ & 18.89 & $3.20 \pm 0.04$ & $0.09 \pm 0.04$ & 16.84 & $4.51 \pm 0.32$ & $0.36 \pm 0.02$ & 12.53 \\
$\mathrm{Cd}$ & $0.21 \pm 0.08$ & $0.07 \pm 0.02$ & 3.00 & $0.21 \pm 0.09$ & $0.09 \pm 0.01$ & 2.33 & $0.31 \pm 0.09$ & $0.11 \pm 0.01$ & 2.82 \\
$\mathrm{Cr}$ & $1.13 \pm 0.08$ & $0.08 \pm 0.01$ & 14.13 & $1.14 \pm 0.07$ & $0.10 \pm 0.01$ & 11.40 & $3.16 \pm 0.09$ & $0.71 \pm 0.02$ & 4.45 \\
Dry matter $(\%)$ & 20.37 & 29.61 & - & 21.15 & 28.12 & - & 18.16 & 27.53 & - \\
\hline
\end{tabular}

Heavy metal concentrations in host-parasite system including Bathybothrium rectangulum and barbel are shown in Table 2. Of the heavy metals evaluated, higher concentrations of $\mathrm{Pb}, \mathrm{Ni}$ and $\mathrm{Cr}$ were regularly found in the strobila of adult tapeworms compared to muscles of parasitized fish. Cadmium did not show any tendency towards higher accumulation in parasites and similar $\mathrm{Cd}$ concentrations were found in the parasite's strobila and in muscles of both the parasitized and non-parasitized fish. Based on the $\mathrm{R}$ values, accumulation effect of $\mathrm{Pb}, \mathrm{Ni}$ and $\mathrm{Cr}$ are relatively balanced (see Table 2). No significant accumulation of $\mathrm{Cd}$ was found in the parasite's strobila $(\mathrm{R} \leq 1)$. Heavy metal concentrations in muscles of parasitized and non-parasitized barbel were different; the concentrations of $\mathrm{Pb}, \mathrm{Ni}$ and $\mathrm{Cr}$ in non-parasitized individuals were higher than those in parasitized individuals, whereas the concentration of $\mathrm{Cd}$ in both groups of individuals was nearly identical. The concentrations of $\mathrm{Pb}$ and $\mathrm{Cr}$ in muscles of non-parasitized fish were slightly lower than the concentrations of these heavy metals in the tapeworm strobila. On the contrary, the Ni concentration in muscles of non-parasitized fish slightly prevailed over that in the tapeworm strobila.

The concentrations of $\mathrm{Cd}, \mathrm{Ni}$ and $\mathrm{Cr}$ in the river water crowfoot (B. fluitans) were evidently higher compared to the tapeworms and both parasitized and non-parasitized fish. Concentrations of $\mathrm{Pb}$ in the plant and fish were similar but slightly lower than that of the parasite strobila (Table 2). 
Table 2. Heavy metals $(\mathrm{Pb}, \mathrm{Cd}, \mathrm{Ni}, \mathrm{Cr})$ concentrations $\left(\mathrm{mg} \cdot \mathrm{kg}^{-1}\right.$ in $100 \%$ dry matter) in strobila of adult tapeworms Bathybothrium rectangulum, in muscles of parasitized and non-parasitized Barbus barbus and in aquatic plant, river water crowfoot (Batrachium fluitans)

\begin{tabular}{lccccc}
\hline \multirow{2}{*}{ Heavy metals } & \multirow{2}{*}{ Parasite } & \multicolumn{2}{c}{ Host-muscle } & Aquatic & $\mathrm{R}$ \\
& & parasitized & non-parasitized & plant & 2.22 \\
$\mathrm{~Pb}$ & $1.31 \pm 0.82$ & $0.60 \pm 0.08$ & $0.82 \pm 0.08$ & $0.81 \pm 0.10$ & 0.88 \\
$\mathrm{Cd}$ & $0.21 \pm 0.04$ & $0.23 \pm 0.05$ & $0.23 \pm 0.04$ & $8.80 \pm 0.18$ & 1.23 \\
$\mathrm{Ni}$ & $1.05 \pm 0.04$ & $0.86 \pm 0.09$ & $1.35 \pm 0.10$ & $3.33 \pm 0.13$ & 2.29 \\
$\mathrm{Cr}$ & $1.87 \pm 0.05$ & $0.82 \pm 0.06$ & $1.39 \pm 0.06$ & $12.68 \pm 0.22$ & - \\
Dry matter $(\%)$ & 19.85 & 28.98 & 30.80 & 11.23 & \\
\hline
\end{tabular}

\section{Discussion}

The bioaccumulation potential of parasites, as a result of competition for chemical elements (including heavy metals), represents a valuable tool to evaluate functions of the host-parasite systems (Sures et al. 1999). Such information is available for larval stages of tapeworm species parasitizing as invasive plerocercoids in the body cavity of intermediate host fishes. Pascoe and Cram (1977) found lower Cd concentrations in plerocercoids of the tapeworm $S$. solidus compared to muscles of its intermediate host i.e. the three-spined stickleback Gasterosteus aculeatus (L.). Gabrashanska and Nedeva (1996) observed regularly higher concentrations of $\mathrm{Cu}, \mathrm{Cr}$ and $\mathrm{Zn}$ (without giving more accurate data) in plerocercoids of $L$. intestinalis than in muscles of the bleak Alburnus alburnus (L.). Our study showed that plerocercoids of L. intestinalis exhibit a specifically different effective bioaccumulation potential for some heavy metals $(\mathrm{Pb}$, $\mathrm{Cd}$ and $\mathrm{Cr}$ ). Similar findings were previously demonstrated by Ten ora et al. (2000) and Baruš et al. (2001). The variability in concentrations of these heavy metals in tapeworm plerocercoids reflects, in our opinion, both the age of the intermediate host fish and the age of plerocercoids, i.e., the time of heavy metal exposition of hosts and parasites in a differently contaminated aquatic environment. This hypothesis is supported by the fact that concentrations of these heavy metals are regularly and significantly higher in older tapeworm plerocercoids (Baruš et al. 2001; Baruš and Prokeš 2002). Similar results were also shown on bioaccumulation and concentrations of some heavy metals in the strobila of adult tapeworms parasitizing in the intestine of definitive fish hosts. Riggs et al. (1987) found that the concentration of selenium (Se) in the strobila of tapeworm Bothriocephalus acheilognathi (Yamaguti, 1934) is $8 \times$ higher than in the muscles of parasitized cyprinid fishes. Turčeková and Hanzelová (1996) stated the $\mathrm{Pb}, \mathrm{Cd}, \mathrm{Zn}, \mathrm{Cu}$ and $\mathrm{As}$ concentrations in the strobila of tapeworm Proteocephalus percae (Müller, 1780) were 200 to $350 \times$ higher than in the muscles of perch Perca fluviatilis (L.). Grabrashanska and Nedeva (1996) ascertained higher $\mathrm{Cu}, \mathrm{Cr}$ and $\mathrm{Zn}$ concentrations in the tapeworm Caryophyllaeus brachycollis (Janiszewska, 1951) compared to their concentrations in muscles of vimba bream Vimba vimba (L.). Sures et al. (1997a) analyzed accumulation of $\mathrm{Pb}$ and $\mathrm{Cd}$ in two tapeworm species, namely Monobothrium wageneri (Nybelin, 1922) parasitizing tench Tinca tinca (L.) and Bothriocephalus scorpii (Müller, 1776) from turbot Scophthalmus maximus (L.). They found that tapeworm $M$. wageneri accumulated $75 \times$ more $\mathrm{Pb}$ and $34 \times$ more $\mathrm{Cd}$ against concentrations found in muscles of the host. In contrast to this observation, an efficient bioaccumulation of $\mathrm{Pb}$ was not found in the tapeworm B. scorpii $(\mathrm{R}=1-2.25)$, however, it was considerably higher for $\mathrm{Cd}(\mathrm{R}=35-60)$. The relation between heavy metals concentration and the age of parasites (i.e. time of exposition) was documented by Riggs et al. (1987) and Sures et al. (1997a) using comparative analysis of anterior 
parts of tapeworms and gravid proglottids of B. acheilognathi and B. scorpii. The analyzed $\mathrm{Pb}, \mathrm{Se}$ and $\mathrm{Cd}$ were characterized by significantly higher concentrations in gravid proglottids. According to our results, bioaccumulation of heavy metals $(\mathrm{Pb}, \mathrm{Cr}$ and $\mathrm{Ni}$ ) in the strobila of $B$. rectangulum is relatively low and comparable with data presented for $\mathrm{Pb}$ by Sures et al. (1997a). The accumulation of $\mathrm{Cd}$ in the strobila of $B$. rectangulum investigated in our study was the lowest compared to all of the above studies. It means that the $\mathrm{Cd}$ concentration in parasites does not markedly differ from that in muscles of the hosts.

All of this suggests that the bioaccumulation capacity for some heavy metals in tapeworms (plerocercoids and adult worms) parasitizing in the body cavity and intestines of host fishes is expressed regularly by higher concentrations in the strobila of tapeworms than in muscles of parasitized hosts. Accumulation of $\mathrm{Cd}$ and $\mathrm{Pb}$, on the contrary, is manifested less markedly $(\mathrm{R}<2)$, with few exceptions (P. percae and B. scorpii). So far it could not be stated unambiguously if this is connected with the influence of external environment (concentration of heavy metals, time of exposition, nutrition of the fish) or with the species-specific accumulation ability of tapeworms.

The parasite's life span (determining the time of exposition in the host) is an important factor in adult tapeworms parasitizing in the intestine of the fish. It is relatively short (one year) compared with a rather long exposition of larval stages parasitizing in cavities and tissues of intermediate host fishes. The function of host-parasite system such is the cyprinid fish and the plerocercoids of $L$. intestinalis is comparable with the life span of intermediate host (Baruš and Prokeš 1995).

Gabrashanska and Nedeva (1996) pointed out an interesting aspect of competition for chemical elements in the host-parasite systems when they found that concentrations of $\mathrm{Cu}$ and $\mathrm{Zn}$ in muscles of fishes ( $V$. vimba, A. alburnus) parasitized by tapeworms (C. brachycollis, L. intestinalis) were lower than those in muscles of non-parasitized fish. Turčeková and Hanzelová (1999) documented such differences for Cd and As in muscles of non-parasitized fish and with tapeworm $P$. percae parasitized muscles of perch. Concentrations of $\mathrm{Cd}$ and As were up to $5 \times$ higher in the non-parasitized than in parasitized fish. On the other hand, concentrations of $\mathrm{Pb}$ in muscles of non-parasitized fish were lower than in parasitized fish. The heavy metals concentrations ascertained during our study in the non-parasitized fish and with the tapeworm $B$. rectangulum parasitized barbel are somewhat different: $\mathrm{Pb}$ in muscles of non-parasitized fish was accumulated $1.37 \times$, Ni $1.57 \times$ and $\mathrm{Cr} 1.7 \times$ more compared to parasitized fish, whereas $\mathrm{Cd}$ concentration was similar in both fish groups.

We consider as very likely the presumption by Turčeková and Hanzelová (1999) that tapeworms may decrease the burden of some heavy metals in their hosts and thus prevent their intoxication. Fish parasites (especially Acanthocephala and Cestoda) are actually considered as useful bioindicator of polluted aquatic environment (Turčeková and Hanzelová 1999; Sures et al. 1997ab, 1999; Sures and Taraschewski 1995). Barbus barbus is also considered a very appropriate indicator to asses the pollution of aquatic environment with Hg (Peňáz et al. 1979, 1980; Svobodová et al. 1996; Spurný et al. 2009). In our study, concentration of two heavy metals ( $\mathrm{Ni}$ and $\mathrm{Cr}$ ) determined in the water crowfoot (B. fluitans) confirmed a high bioaccumulation potential of aquatic macrophytes (see Peňáz et al. 1980; Svobodová et al. 1996).

Heavy metal concentrations in fish (definite or intermediate hosts of tapeworms) are measured in certain organs, e.g. muscles or liver, whereas the heavy metals in the body of tapeworms reflect their concentration in the entire parasite's organism. In this respect, the knowledge of heavy metals in parasites may serve as a convenient and additional bioindicator for evaluating environmental pollution of aquatic ecosystems. 


\section{Acknowledgement}

Research presented in this study was supported financially by the Institutional Research Plan AVOZ60930519. Andrea Šimková was supported by the project of the Grant Agency of the Czech Republic no. P505/10/1138. We acknowledge also the linguistic revision by Kevin Roche.

\section{References}

Baruš V, Prokeš M 1995: Length-weight relationship of Ligula intestinalis plerocercoids in adult Blicca bjoerkna and discussion on estimation of parasite age. Appl Parasitol 36: 192-199

Baruš V, Prokeš M 2002: Length and weight of Ligula intestinalis plerocercoids (Cestoda) parasitizing cyprinid fishes (Cyprinidae): a comparative analysis. Helminthologia 39: 29-34

Baruš V, Tenora F, Kráčmar S, Dvořáček J 1999: Contents of several inorganic substances in European eel infected and uninfected by Anguillicola crassus (Nematoda). Dis Aquat Org 37: 135-137

Baruš V, Tenora F, Kráčmar S, Prokeš M 2001: Accumulation of heavy metals in plerocercoids of Ligula intestinalis (Pseudophyllidea) of different age. Helminthologia 38: 29-33

Gabrashanska M, Nedeva I 1996: Content of heavy metals in the system fish-cestodes. Parassitologia 38, p. 58

Pascoe D, Cram P 1977: The effect of parasitism on the toxicity of cadmium to the three-spines stickleback, Gasterosteus aculeatus L. J Fish Biol 10: 467-472

Peňáz M, Baruš V, Prokeš M 2002: Concentrations of heavy metals and changes in concentrations of the mercury in tissues of the barbel (Barbus barbus) from the River Jihlava (in Czech with English summary). Proc. of the Czech Conference of Ichthyology, Brno 2002, pp. 253-258

Peňáz M, Svobodová Z, Hejtmánek M, Trnková J 1979: Mercury contents in muscles of fishes from the Jihlava River. Folia Zool 28: 171-176

Peňáz M, Svobodová Z, Hejtmánek M, Trnková J, Wohlgemuth E 1980: Mercury contents in the basic components of Jihlava river ecosystem (in Czech). Bulletin VÚRH Vodňany 1: 24-30

Riggs M R, Lemly A D, Esch G W 1987: The growth, biomass and fecundity of Bothriocephalus acheilognathi in a North Carolina reservoir. J Parasitol 73: 893-900

Spurný P, Mareš J, Hedvábný J, Sukop I 2009: Residual metal contamination of the ecosystem in the lower courses of the Jihlava River. Acta Vet Brno 78: 525-534

Sures B, Siddal R, Taraschewski H 1999: Parasites as accumulation indicators of heavy metal pollution. Parasitol Today 15: 16-21

Sures B, Taraschewski H 1995: Helminths of fish: reliable indicators of heavy metal pollution in aquatic ecosystems? Bull Scand Soc Parasit 5: 73

Sures B, Taraschewski H, Rokicki J 1997a: Lead and cadmium content of two cestodes, Monobothrium wageneri and Bothriocephalus scorpii, and their fish host. Parasitol Res 83: 618-623

Sures B, Taraschewski H, Siddal R 1997b: Heavy metal concentrations in adult acanthocephalans and cestodes compared to their fish host and to established free living bioindicators. Parassitologia 39: 213-218

Svobodová Z, Hejtmánek, M 1985: Total mercury content in the components of running water, reservoir and pond ecosystems in Czechoslovakia. Symp. Biologica Hungarica 29: 171-177

Svobodová Z, Dušek L, Hejtmánek M, Vykusová B, Šmíd R 1999: Bioaccumulation of mercury in various fish species from Orlík and Kamýk water reservoirs in the Czech Republic. Ecotox Environ Safe 43: 231-240

Svobodová Z, Máchová J, Vykusová B, Piačka V 1996: The heavy metals in water ecosystems (in Czech). Edice metodik, č. 49. VÚRH Vodňany, pp. 1-19

Taraschewski H, Sures B 1996: Heavy metal concentrations in parasites compared to their fish hosts: bioconcentration by acanthocephalans and cestodes. Parassitologia 38: 65

Tenora F, Kráčmar S, Baruš V, Dvořáček J 1997: Some anorganic substances in plerocercoids of Ligula intestinalis (Pseudophyllidea). Acta Univ Agric Silvic Mendelianae Brunensis 95: 23-30

Tenora F, Kráčmar S, Baruš V, Dvořáček J 2000: Concentrations of some heavy metals in Ligula intestinalis plerocercoids (Cestoda) and Philometra ovata (Nematoda) compared to some their host (Osteichthyes). Helminthologia 37: 15-18

Turčeková L, Hanzelová V 1996: Concentration of heavy metals in cestode Proteocephalus percae, parasite of perch. Helminthologia 33: 162-163

Turčeková L, Hanzelová V 1999: Concentrations of Cd, As and Pb in non-infected and infected Perca fluviatilis with Proteocephalus percae. Helminthologia 36 (Suppl.): p. 31

Valová Z, Jurajda P, Janáč M, Bernardová I, Hudcová D 2010: Spatiotemporal trends of heavy metal concentrations in fish of the River Morava (Danube basin). J Environ Sci Heal A 45: 1892-1899 